\title{
Synthesis, Characterization and Antibacterial Activity Study of Cobalt(II), Nickel(II), Copper(II), Palladium(II), Cadmium(II) and Platinum(IV) Complexes with 4-Amino-5- (3,4,5-trimethoxyphenyl)-4H-1,2,4-triazole-3-thione
}

\author{
Waleed Abbas Jawad ${ }^{1}$, Asim Alaa Abd Al-Hussein Balakit ${ }^{2}$, and Mahmoud Najim Abid Al-Jibouri ${ }^{3 *}$ \\ ${ }^{1}$ Ministry of Education, Babylon Education Directorate, Hilla-Iraq \\ ${ }^{2}$ College of Pharmacy, University of Babylon, Hilla-Iraq \\ ${ }^{3}$ Department of Chemistry, College of Science, Mustansiriyah University, Baghdad-Iraq
}

\section{*Corresponding author:}

email:mahmoudaljibouri@gmail.com

Received: June 25, 2021

Accepted: August 8, 2021

DOI: $10.22146 /$ ijc. 67021

\begin{abstract}
New transition metal complexes of cobalt(II), nickel(II), copper(II), palladium(II), cadmium(II), and platinum(IV) with bidentate ligand 4-amino-5-(3,4,5trimethoxyphenyl)-4H-1,2,4-triazole-3-thiol were synthesized and characterized by microelemental analyses (CHNS), Fourier-transform infrared (FT-IR), UV-Visible spectra, molar conductance, magnetic susceptibility and thermal analyses (TG-DSC). The ligand was synthesized by ring closure of potassium-2-(3,4,5-trimethoxybenzoyl) hydrazine carbodithioate with an excess amount of hydrazine, and then was acidified using hydrochloric acid. The ligand was used as Lewis bases to prepare metal complexes through the reaction of ratio (1:2) metal:ligand. The ligand was characterized by ${ }^{1} \mathrm{H}-\mathrm{NMR}$ and ${ }^{13} C-N M R$ and the previously described methods to identify the complexes. The results obtained from spectra and elemental analyses indicated the tetrahedral geometry around $C d(I I)$ ion, square-planar for $\mathrm{Cu}(I I)$ and $P d(I I)$, and octahedral geometry around Co(II), $\mathrm{Ni}(I I)$, and $\mathrm{Pt}(\mathrm{IV})$. All the metal complexes showed significant antibacterial activity in comparison with the free ligand. The antibacterial test of the platinum(IV) complex showed higher activity than other metal complexes against bacteria Staphylococcus aureus (G-positive) and Escherichia coli (G-negative).
\end{abstract}

Keywords: 1,2,4-triazole-3-thione derivatives; new metal complexes; antibacterial activity

\section{- INTRODUCTION}

The 1,2,4-triazole parent consists of a fivemembered aromatic ring containing three atoms of nitrogen, two of which are adjacent to a stable, watersoluble solid. It is possible to envisage two tautomeric forms, $1 H$-tautomer and $4 H$-tautomer. Theoretical and empirical approaches suggest that the preferred structure is the $1 \mathrm{H}$-tautomer. Two nitrogen atoms are connected to any carbon atom in 1,2,4-triazole, and thus, the ring structure is deficient in electrons. For electrophilic attack, the ring is deactivated so that nitration and other typical carbon reactions of aromatic chemistry do not occur to the parent compound. However, in the literature, electrophilic attacks on nitrogen are found in abundance [1-2].

3-Mercapto-1H-1,2,4-triazol-5-yl derivatives have been reported in numerous studies, a thiol-thione group leading to an increase in biological activity linked to the triazole moiety [3]. In addition, the triazolethione system is known as a cyclic analog of very significant components such as thiosemicarbazides and thiocarbohydrazides, which are widely distributed in many organic reactions as a reactive building block leading to deferential heterocyclic rings and successful biological applications. The nucleus of mercapto-1,2,4triazole is also present in many natural products and pharmaceuticals [4]. Those having 1,2,4-riazole thione-

Waleed Abbas Jawad et al. 
thiol derivatives have gained considerable importance in medicinal chemistry due to their anticancer [5], antimicrobial [6], antioxidant, antitumor, antituberculosis, anticonvulsant [7], fungicidal [8], antiepileptic, and anti-inflammatory activities [9]. The interaction of these donor ligands and metal ions gives complexes of different geometries, and a literature survey reveals that these complexes are potentially more biologically active [5]. Dallavalle et al. [10] synthesized copper(II) and palladium(II) complexes of 4-amino-5methylthio-3-(2-pyridyl)-1,2,4-triazole. These complexes' antiproliferative activity and ligands were assessed on regular human fibroblasts (HF) and human fibrosarcoma tumor (HT1080) cells. The copper(II) complex displayed potent antiproliferative activity for both normal and neoplastic cells. Al-Masoudi et al. [11], identified mixed ligand complexes of 4,5-diphenyl-1,2,4-triazole-3-thione (LH) and diphosphines $\mathrm{Ph}_{2} \mathrm{P}\left(\mathrm{CH}_{2}\right) \mathrm{nPPh}_{2}$ with platinum(II) and palladium(II). The antiproliferative activity of these complexes was evaluated against a panel of human cancer cell lines derived from hematological CD4+ human T-cells with an integrated HTLV-1 genome (MT-4). The platinum-based complex was the most active in the series, with antiproliferative activity against various cancer cell lines. The present work described the synthesis of some transition metal complexes with bidentate ligand 4-amino-5-(3,4,5-trimethoxyphenyl)-4H-1,2,4-triazole-3thiol, and then antibacterial activity study of the ligand and their metal complexes.

\section{- EXPERIMENTAL SECTION}

\section{Materials}

All starting materials, namely gallic acid and hydrazine hydrate, were used in this study without further purification. All chemicals including $\mathrm{CoCl}_{2} \cdot 6 \mathrm{H}_{2} \mathrm{O}$, $\mathrm{CuCl}_{2} \cdot 2 \mathrm{H}_{2} \mathrm{O}, \mathrm{NiCl}_{2} \cdot 4 \mathrm{H}_{2} \mathrm{O}, \mathrm{CdCl}_{2} \cdot 2 \mathrm{H}_{2} \mathrm{O}, \mathrm{H}_{2} \mathrm{PtCl}_{6} \cdot 2 \mathrm{H}_{2} \mathrm{O}$ and $\mathrm{PdCl}_{2}$ were procured from Sigma-Aldrich and $\mathrm{CDH}$.

\section{Instrumentation}

Electrical conductivity measurements of the complexes were made with $10^{-3} \mathrm{M}$ of DMF solvent at $25^{\circ} \mathrm{C}$ using WTW Cond 7300 digital conductivity meter. Melting points of the ligands and their metal ion complexes were measured using Stuart SMP 10 UK at the College of Pharmacy, the University of Babylon. The electronic spectra of the ligands and their ion metal complexes were recorded on an 1800-UV Shimadzu spectrophotometer in the range of $200-1100 \mathrm{~nm}$ using quartz cell of length $1 \mathrm{~cm}$ and concentration $10^{-3} \mathrm{M}$ by using DMSO as a solvent at the College of Pharmacy, University of Babylon. Infra-red spectra are recorded in the range $4000-500 \mathrm{~cm}^{-1}$ using $\mathrm{KBr}$ disk for the ligands and CsI disk in the range $4000-200 \mathrm{~cm}^{-1}$ for their complexes (Bruker Optics, Japan) College of Pharmacy, the University of Babylon. Magnetic susceptibility measurements for the synthesized complexes have been measured at room temperature using Auto Magnetic Susceptibility Balance Model Sherwood Scientific at Department of Chemistry, College of Sciences, AlMustansiriyah University. The spectra of ${ }^{1} \mathrm{H}-\mathrm{NMR}$ and ${ }^{13} \mathrm{C}$-NMR have been measured using Bruker Bio-Spin $\mathrm{GmbH} 400 \mathrm{MHz}$ and $100 \mathrm{MHz}$ instruments with tetramethylsilane as the internal standard. The mass spectra for the intermediate and ligand were recorded with Shimadzu QP-1000EX GC/MS instrument, Japan, at the Department of Chemistry, College of Sciences, Mustansiriyah University. The metal contents of the synthesized complexes were determined by using FL Aspect LS 131 RC1 at Ibn-Sina Center, Baghdad, Iraq. Thermal analysis of the synthesized ligand and its metal complexes was measured using Shimadzu 60-H Thermal Analyzer at Vit Vellore, Perkin Elmer STA6000 thermal analyzer, the National Center for Research and Development Science and Materials Engineering, Iran. The ligands' carbon, hydrogen, nitrogen, and sulfur contents and their metal ion complexes were recorded on a Vario ELV5 CHNS Mode, S. No.: 11086109, at the National center for research and development science and materials engineering, Iran.

\section{Synthesis}

\section{Synthesis of 3,4,5-trimethoxybenzoic acid (S1)}

Gallic acid monohydrate $25 \mathrm{~g}(0.133 \mathrm{~mol})$ was added to a cold solution of $40 \mathrm{~g}(1.0 \mathrm{~mol})$ sodium hydroxide in $250 \mathrm{~mL}$ water in a 3-neck round bottom flask. The flask was closely stopped immediately, and the 
mixture was periodically mixed until all of the acids were dissolved. First, dimethyl sulfate $0.36 \mathrm{~mol}(33 \mathrm{~mL})$ was added, and the flask was stirred for $20 \mathrm{~min}$. In order to prevent the temperature from increasing above $30-35^{\circ} \mathrm{C}$, the mixture was kept cold. The cover was occasionally lifted to release some pressure. Next, a second similar volume of dimethyl sulfate was added, and stirring continued for a greater range of $20 \mathrm{~min}$. The temperature increased to $40-45{ }^{\circ} \mathrm{C}$ during this second addition. The flask was then fitted with a reflux condenser, and the contents were cooked for two hours by stirring. Sodium hydroxide $(10 \mathrm{~g})$ was then added to $15 \mathrm{~mL}$ of water, and the boiling continued for an additional two hours. The reaction mixture was then cooled and acidified with 5\% hydrochloric acid. The precipitated was filtered with suction and washed well with cold water and recrystallized from ethanol to give a compound of $\mathrm{S} 1$ as given in Scheme 1 [12] Color (brown crystal), yield (85\%), M.p (170-172) ${ }^{\circ} \mathrm{C}$, M.wt (212 g/mol), FT-IR $\left(\mathrm{KBr}, \mathrm{cm}^{-1}\right)$ : broad bend $v(\mathrm{O}-\mathrm{H})(3020-2516), v(\mathrm{C}=\mathrm{O})$ acid (1681), vC-H aliph. (2945 and 2836).

\section{Synthesis of 3,4,5-trimethoxymethylbenzoate (S2)}

Sulfuric acid $(1.5 \mathrm{~mL})$ was added dropwise to the mixture of compound S1 (10.6 g, $0.05 \mathrm{~mol}$ ) in $30 \mathrm{~mL}$ methanol for $8 \mathrm{~h}$. The mixture was heated under reflux, and the reaction was controlled using thin-layer chromatography (TLC). After cooling, the precipitate formed and the methanol excess was evaporated. The solid product was washed with a solution of sodium bicarbonate, filtered, washed with cold water, dried, and recrystallized from ethanol to give compound of S2, as presented in Scheme 1 [13]: Color (white crystal), Yield (95\%), M.p (83-85 $\left.{ }^{\circ} \mathrm{C}\right)$, M.wt $(226 \mathrm{~g} / \mathrm{mol}), \mathrm{R}_{\mathrm{f}}=0.87$ (ethyl acetate:chloroform, 1:2). FT-IR $\left(\mathrm{KBr}, \mathrm{cm}^{-1}\right)$ : $v(\mathrm{C}=\mathrm{O})$ ester (1713), $v \mathrm{C}-\mathrm{H}$. (3079), $v \mathrm{C}-\mathrm{H}$ aliph. (2951).

\section{Synthesis of 3,4,5-trimethoxybenzohydrazide (S3)}

To the solution of compound S2 prepared by dissolving $9 \mathrm{~g}(0.04 \mathrm{~mol})$ in $40 \mathrm{~mL}$ of absolute ethanol, $15 \mathrm{~mL}$ of hydrazine hydrate (80\%) was added. The mixture was refluxed for $14 \mathrm{~h}$, the reaction was controlled using thin-layer chromatography (TLC), and then the mixture was allowed to cool down. Finally, a<smiles>C=C(O)c1cc(OC)c(OC)c(OC)c1</smiles>

Gallic acid

S1

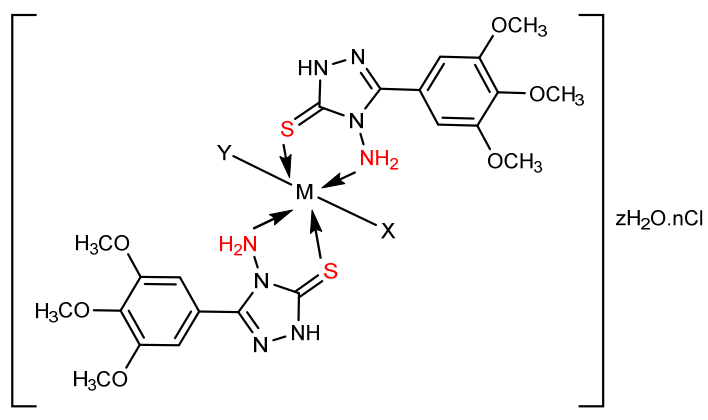

i- $\mathrm{MCl}$. $2 \mathrm{H} 2 \mathrm{O}, \mathrm{M}=\mathrm{Co}(\mathrm{II}), \mathrm{Ni}(\mathrm{II}), \mathrm{Cu}(\mathrm{II}), \mathrm{Cd}(\mathrm{II}), \mathrm{Pd}(\mathrm{II}), \mathrm{Pt}(\mathrm{IV})$

$\mathrm{C} 1-\mathrm{X}, \mathrm{Y}=\mathrm{Cl}, \mathrm{Z}, \mathrm{n}=0$

$\mathrm{C} 2-\mathrm{X}, \mathrm{Y}=\mathrm{Cl}, \mathrm{z}, \mathrm{n}=0$

$\mathrm{C} 3-\mathrm{X}, \mathrm{Y}=0, \mathrm{Z}=0, \mathrm{n}=2$

$\mathrm{C} 4-\mathrm{X}, \mathrm{Y}=0, \mathrm{z}=1, \mathrm{n}=2$

$\mathrm{C} 5-\mathrm{X}, \mathrm{Y}=0, \mathrm{z}=0, \mathrm{n}=2$

$\mathrm{C} 6-\mathrm{X}, \mathrm{Y}=\mathrm{Cl}, \mathrm{z}=2, \mathrm{n}=2$

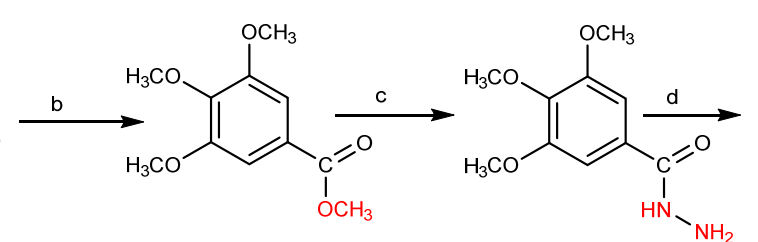

S2

s3<smiles>COc1cc(C(=O)NN)cc(OC)c1OC</smiles>
S4<smiles>C1CCCCC1</smiles>

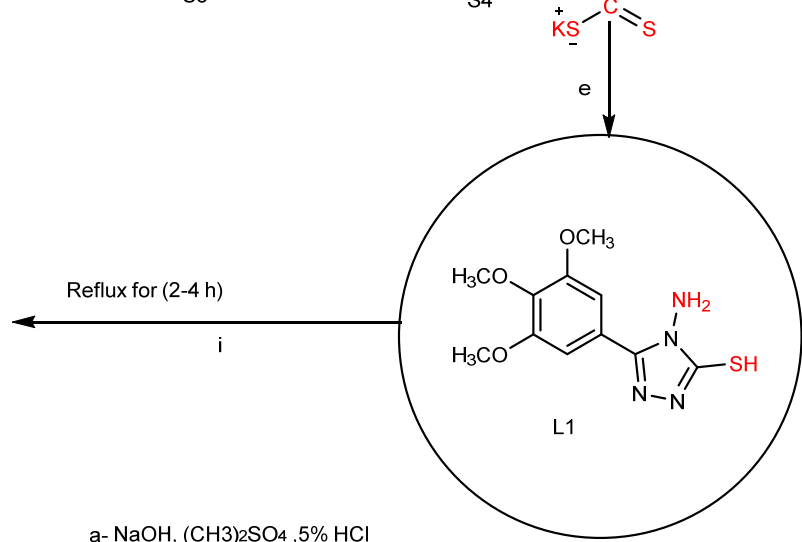

b- $\mathrm{H}_{2} \mathrm{SO}_{4}, \mathrm{NaHCO}_{3}, \mathrm{CH}_{3} \mathrm{OH}$

c- $\mathrm{N} 2 \mathrm{H} 4 . \mathrm{H} 2 \mathrm{O} 80 \%, \mathrm{C} 2 \mathrm{H} 5 \mathrm{OH}$

d- $\mathrm{KOH}, \mathrm{CS}_{2}, \mathrm{CH}_{3} \mathrm{OH}$, at $\mathrm{OCO}, \mathrm{C}_{2} \mathrm{H}_{5} \mathrm{OC} 2 \mathrm{H} 5$

e- $\mathrm{N}_{2} \mathrm{H}_{4} . \mathrm{H}_{2} \mathrm{O} 80 \%, \mathrm{HCl}$ pH=2-3

Scheme 1. Synthesis of L and their complexes C1-C6 
solid product was filtered, washed with cold water, dried, and recrystallized from ethanol to give compound S3, Scheme 1 [14]: Color (white), Yield (90\%), M.p (160$163{ }^{\circ} \mathrm{C}$ ), M.wt $(226 \mathrm{~g} / \mathrm{mol}), \mathrm{R}_{\mathrm{f}}=0.25$ (ethyl acetate: chloroform, 1:2). FT-IR $\left(\mathrm{KBr}, \mathrm{cm}^{-1}\right): v\left(\mathrm{NH}_{2}\right)$ asym. and sym. (3366 and 3334), v(NH) (3292), $v(\mathrm{C}=\mathrm{O})$ amide (1651), vC-H arom. (3010), vC-H aliph. (2938).

\section{Synthesis of potassium-2-(3,4,5-trimethoxybenzoyl) hydrazine carbodithioate (S4)}

Compound S3 $(4.5 \mathrm{~g}, 0.0195 \mathrm{~mol})$ was treated with a solution of $1.8 \mathrm{~g}(0.0321 \mathrm{~mol})$ of potassium hydroxide in $35 \mathrm{~mL}$ methanol at $0{ }^{\circ} \mathrm{C}$ with stirring. Carbon disulfide $(0.2 \mathrm{~mol}, 7 \mathrm{~mL})$ was added dropwise, and the reaction mixture was stirred overnight at room temperature. And then, $100 \mathrm{~mL}$ diethyl ether was added to cool the reaction with stirred for $10 \mathrm{~min}$. Finally, the solid product was filtered, washed with cold methanol, and dried to give compound S4, Scheme 1 [15]: Color (pale yellow powder), Yield (95\%), M.p (225-227 $\left.{ }^{\circ} \mathrm{C}\right)$, M.wt (340 g/mol), FT-IR $\left(\mathrm{KBr}, \mathrm{cm}^{-1}\right): v(\mathrm{NH})(3275-3223), v(\mathrm{C}=\mathrm{O})$ amide (1649), $v(\mathrm{C}=\mathrm{S})$ (1262), $v \mathrm{C}-\mathrm{H}$ arom. (2998), $v \mathrm{C}-\mathrm{H}$ aliph. (2939).

\section{Synthesis of 4-amino-5-(3,4,5-trimethoxiyphenyl)-4H- 1,2,4-triazole-3-thione, $L$}

A compound $\mathrm{S} 4(4.5 \mathrm{~g}, 0.0132 \mathrm{~mol})$ in an excess amount of hydrazine hydrate (about $25 \mathrm{~mL}$ ) was heated under reflux for $6 \mathrm{~h}$. A color change of mixture from black-green into light yellow is to release hydrogen sulfide gas by changing the lead acetate sheet from black to white. The reaction was controlled using thin-layer chromatography (TLC). The cooled mixture was poured into ice water $(30 \mathrm{~mL})$ and acidified with conc. hydrochloric acid $(\mathrm{pH}=2-3)$. The precipitate was filtered, washed with cold water, dried and recrystallized from ethanol to give ligand (L1), Scheme 1 [16]: Color (grey powder), Yield (55\%), M.p (214-216 $\left.{ }^{\circ} \mathrm{C}\right)$, M.wt (282 g/mol), $\mathrm{R}_{\mathrm{f}}=0.5$ (ethyl acetate:chloroform, 1:2). FT-IR $\left(\mathrm{KBr}, \mathrm{cm}^{-1}\right)$ : $v\left(\mathrm{NH}_{2}\right)$ asym. and sym.(3300 and 3247), $v(\mathrm{NH})(3189)$, $v(\mathrm{~S}-\mathrm{H}) \quad(2728), \quad v(\mathrm{C}=\mathrm{S}) \quad(1237) .{ }^{1} \mathrm{H}-\mathrm{NMR} \quad(400 \mathrm{MHz}$, $\mathrm{CDCl} 3, \delta \mathrm{ppm}$ ): 10.33 (s, weak, $\mathrm{SH}), 7.46$ (s, 2H, aromatic), 4.89 (S, broad, $\left.\mathrm{NH}_{2}\right) 3.9\left(\mathrm{~s}, 6 \mathrm{H}, 2 \mathrm{OCH}_{3}\right), 3.8(\mathrm{~s}$, $\left.3 \mathrm{H}, \mathrm{OCH}_{3}\right),{ }^{13} \mathrm{C}-\mathrm{NMR}(100-\mathrm{MHz}, \mathrm{DMSO}) 56.60,56.65$,
$60.64,105.77,125.86,139,88,149.63,153.28,167.09 . \mathrm{MS}$ $(\mathrm{m} / z \%): 282\left[\mathrm{M}^{+}\right]$.

\section{Synthesis of the metal complexes from (C1-C6)}

Complexes were synthesized by dissolving $2 \mathrm{mmol}$ $(0.564 \mathrm{~g})$ of ligand $\mathrm{L} 1$ in $15 \mathrm{~mL}$ ethanol absolute and mixing with $15 \mathrm{~mL}(1 \mathrm{mmol})$ of the metal ion $\left(\mathrm{CoCl}_{2} \cdot 6 \mathrm{H}_{2} \mathrm{O}, \mathrm{CuCl}_{2} \cdot 2 \mathrm{H}_{2} \mathrm{O}, \mathrm{NiCl}_{2} \cdot 4 \mathrm{H}_{2} \mathrm{O}, \mathrm{CdCl}_{2} \cdot 2 \mathrm{H}_{2} \mathrm{O}\right.$, $\mathrm{H}_{2} \mathrm{PtCl}_{6} 2 \mathrm{H}_{2} \mathrm{O}$ and $\mathrm{PdCl}_{2}$ in 1:2 as a mol ratio of metal to the ligand following Scheme 1. The mixture was left under reflux for 2-4 $\mathrm{h}$ and then allowed the solid complexes to be cooled and added $10 \mathrm{~mL}$ of diethyl ether to precipitate. Next, the crystals were filtered and washed with cold water and ethanol. It was followed with drying and then recrystallized with ethanol. Table 1 shows the percentage yield and physical characteristics of the ligand and its complexes.

\section{- RESULTS AND DISCUSSION}

The metal complexes prepared in the recent study were non-hygroscopic (stable at room temperature) and amorphous solids. The solubility of the metal complexes in common organic solvents was investigated. It was discovered that all complexes were sparingly soluble in methanol, ethanol, and chloromethane but were highly soluble in DMSO, DMF, and chloroform. When the results of (CHNS) tests agree with their calculated values, the expected structures and molecular formulas are verified. Except for the cobalt(II) and nickel(II) complexes, the molar conductance data of complexes solutions in DMF revealed electrolytic properties, conductive between $135-168 \mathrm{ohm}^{-1} \mathrm{~cm}^{2} \mathrm{~mol}^{-1}$ shown in Table 1.

\section{FT-IR Spectral Study}

The FT-IR spectrum of ligand L1 showed some characteristic stretching bands at $33013253,2724,1608$, and $1236 \mathrm{~cm}^{-1}$, which are assigned to $v\left(\mathrm{NH}_{2}\right), v(\mathrm{~S}-\mathrm{H})$, $v(\mathrm{C}=\mathrm{N})$ of triazole ring and the stretching of $\mathrm{C}=\mathrm{S}$ bond, respectively. These bands in all-metal complexes C1-C6 demonstrated significant changes in the positions and intensities as the complexation results [17-18] as given in Fig. S1-S2 (see Supplementary Data). Thus, the tautomerism form could occur in the triazole ring, and 
Table 1. Physical properties and analytical data of the Schiff base ligand (L1) and its metal complexes

\begin{tabular}{|c|c|c|c|c|c|c|c|c|c|c|}
\hline \multirow{2}{*}{ Symbol } & \multirow{2}{*}{ l Compound } & \multirow{2}{*}{ Color } & \multirow{2}{*}{ M.wt } & \multirow{2}{*}{$\begin{array}{l}\text { Yield } \\
\%\end{array}$} & \multirow{2}{*}{ M.p c ${ }^{\circ}$} & \multicolumn{4}{|c|}{ Micro Elemental Analysis Found (calc.) } & \multirow{2}{*}{$\begin{array}{l}\text { Metal content } \\
\text { Found (calc.) }\end{array}$} \\
\hline & & & & & & $\mathrm{C} \%$ & $\mathrm{~N} \%$ & $\mathrm{H} \%$ & S\% & \\
\hline \multirow[t]{2}{*}{$\mathrm{L}}$. & $\mathrm{C}_{11} \mathrm{H}_{14} \mathrm{~N}_{4} \mathrm{O}_{3} \mathrm{~S}$ & White & 282 & 55 & $214-216$ & $(46.80)$ & $(19.85)$ & $(5.00)$ & $(11.36)$ & \\
\hline & & & & & & 45.55 & 19.23 & 4.56 & 11.89 & - \\
\hline \multirow[t]{2}{*}{$\mathrm{C} 1$} & $\left.[\mathrm{CoL})_{2} \mathrm{Cl}_{2}\right]$ & Brown & 694.7 & 67 & $225-227$ & $(38.05)$ & $(16.14)$ & $(4.06)$ & $(9.23)$ & $(8.49)$ \\
\hline & & & & & & 37.98 & 16.78 & 3.84 & 9.08 & 7.91 \\
\hline \multirow[t]{2}{*}{$\mathrm{C} 2$} & {$\left[\mathrm{Ni}(\mathrm{L})_{2} \mathrm{Cl}_{2}\right]$} & Pale blue & 694.2 & 64 & $219-221$ & $(38.06)$ & $(16.14)$ & $(4.07)$ & $(9.24)$ & $(8.45)$ \\
\hline & & & & & & 37.78 & 16.33 & 3.19 & 9.29 & 8.11 \\
\hline \multirow[t]{2}{*}{$\mathrm{C} 3$} & {$\left[\mathrm{Cu}(\mathrm{L})_{2}\right] \mathrm{Cl}_{2}$} & Dark & 699.1 & 72 & $290-292$ & $(37.80)$ & $(16.03)$ & $(4.04)$ & $(9.17)$ & (9.09) \\
\hline & & gray & & & & 36.89 & 15.43 & 4.21 & 9.65 & 8.67 \\
\hline \multirow[t]{2}{*}{$\mathrm{C} 4$} & {$\left[\mathrm{Pd}(\mathrm{L})_{2}\right] \mathrm{Cl}_{2} \cdot \mathrm{H}_{2} \mathrm{O}$} & Dark & 741.9 & 69 & $296 \mathrm{dec}$ & $(35.96)$ & $(15.10)$ & $(3.80)$ & $(8.64)$ & (14.34) \\
\hline & & brown & & & & 35.65 & 15.78 & 3.36 & 8.45 & 14.89 \\
\hline \multirow[t]{2}{*}{ C5 } & {$\left[\mathrm{Cd}(\mathrm{L})_{2}\right] \mathrm{Cl}_{2}$} & Off white & 747.9 & 71 & $241-243$ & $(35.33)$ & $(14.98)$ & $(3.77)$ & $(8.57)$ & (15.03) \\
\hline & & & & & & 34.92 & 14.49 & 3.21 & 8.04 & 14.67 \\
\hline \multirow[t]{2}{*}{ C6 } & {$\left[\mathrm{Pt}(\mathrm{L})_{2} \mathrm{Cl}_{2}\right] \mathrm{Cl}_{2} \cdot 2 \mathrm{H}_{2} \mathrm{O}$} & Pale & 937.5 & 59 & $272 \mathrm{dec}$ & $(28.18)$ & $(11.95)$ & $(3.44)$ & $(6.84)$ & $(20.81)$ \\
\hline & & brown & & & & 28.76 & 11.40 & 3.76 & 6.59 & 21.21 \\
\hline
\end{tabular}

it is responsible for the disappearance of the thiol functional group in the ligand molecule after complexation. After tautomerism forms, the ligand can link with the metal ion either by $\mathrm{N}$ or the thioamide group's $S$. Bonding at $S$ is favorable because it would result in a stable five-membered chelate [19]. The exceptional case is that the $v(\mathrm{C}=\mathrm{N})$ of complexes $\mathrm{C} 1-\mathrm{C} 6$ were found to be shifted to a lower wavelength number compared to the ligand L1, signifying that the coordination took place via the nitrogen atom of the ligand L1 [20]. The frequencies of $v\left(\mathrm{NH}_{2}\right)$ sym. and asymmetric bands were shift due to complexation. The band of $v(\mathrm{~S}-\mathrm{H})$ in the ligand was disappeared when complexation occurred, and the bands of $v(\mathrm{C}=\mathrm{S})$ also shifted to the higher or lower frequency due to an increase of the bond order of carbon- sulfate bond result from complexation of the metal ion to the ligand through sulfate. Another new band was appeared, which was supported by the appearance frequencies of (M-S), (M-N), and (M-Cl) [21-22]. The major FT-IR bands and their probable assignment are given in Table 2.

\section{Mass Spectral Studies}

The mass spectrum of ligand L1 in Fig. S3 showed several peaks attributed to the presence of 1,2,4-triazole rings. This spectrum showed the mother ion peak at $m / z$ : 282 as a base peak for L1 and peaks at $m / z 249,235,165$, 193, and 134 for the triazole ring. The most characteristic fragments of this compound were illustrated in Scheme 2.

Table 2. FT-IR data of ligand L1 and their complexes

\begin{tabular}{lccccccc}
\hline No & $\begin{array}{l}v_{\text {as,s }}\left(\mathrm{NH}_{2}\right) \\
v_{\text {as, }}(\mathrm{O}-\mathrm{H})\end{array}$ & $v(\mathrm{~S}-\mathrm{H})$ & $v(\mathrm{C}=\mathrm{N})$ & $v(\mathrm{C}=\mathrm{S})$ & $v(\mathrm{M}-\mathrm{N})$ & $v(\mathrm{M}-\mathrm{S})$ & $v(\mathrm{M}-\mathrm{Cl})$ \\
\hline $\mathrm{L}$ & 3301,3253 & 2724 & 1608 & 1236 & - & - & - \\
$\mathrm{C} 1$ & 3293,3214 & - & 1600 & 1236 & 486 & 358 & 314 \\
$\mathrm{C} 2$ & 3284,3214 & - & 1600 & 1236 & 485 & 350 & 304 \\
$\mathrm{C} 3$ & 3298,3223 & - & 1604 & 1216 & 484 & 361 & 315 \\
$\mathrm{C} 4$ & 3218,3400 & - & 1587 & 1218 & 460 & 380 & 302 \\
$\mathrm{C} 5$ & 3293,3241 & - & 1601 & 1239 & 485 & 350 & 315 \\
$\mathrm{C} 6$ & 3479,3122 & - & 1590 & 1226 & 482 & 369 & 315 \\
\hline
\end{tabular}

Waleed Abbas Jawad et al. 

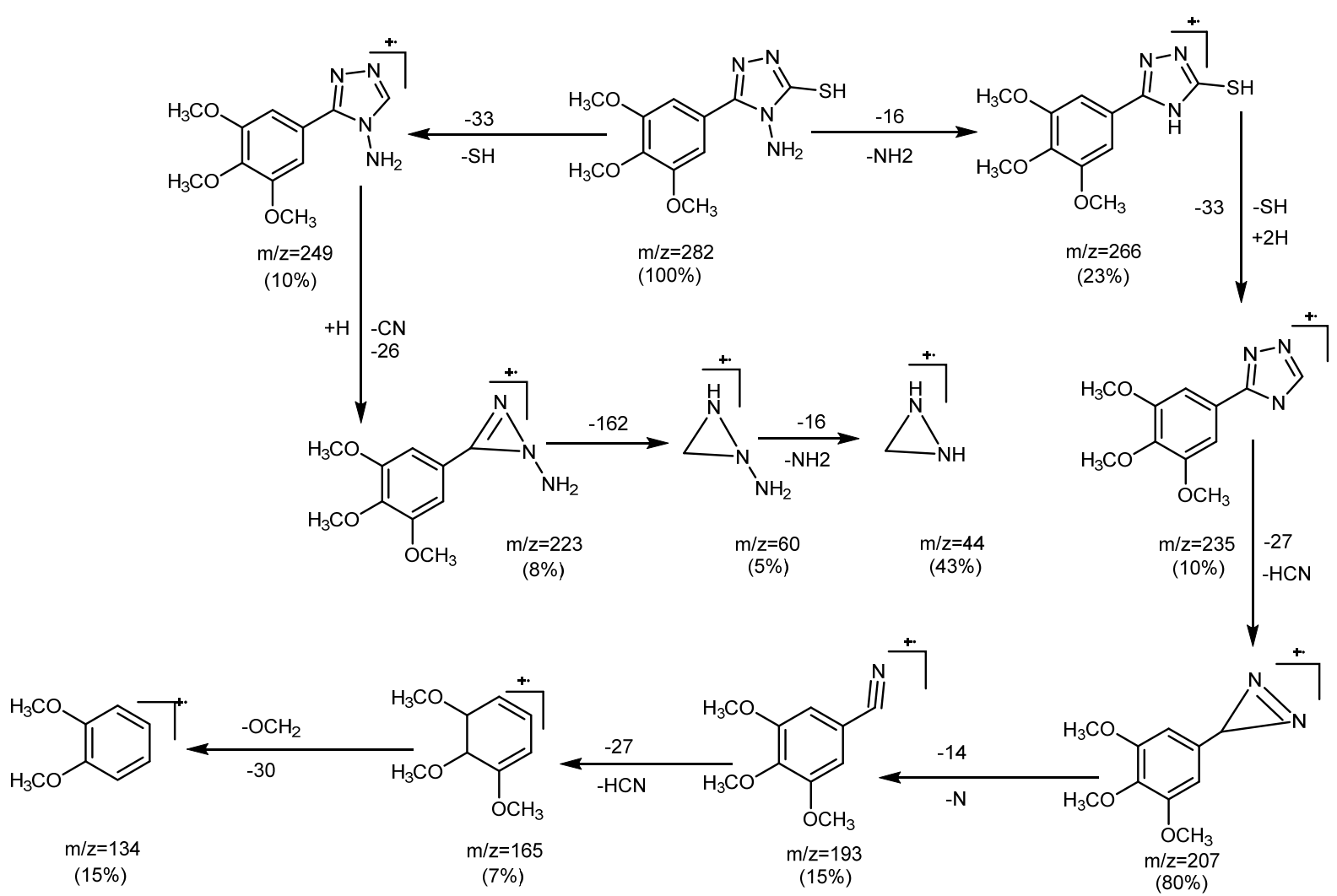

Scheme 2. Proposed Mass fragmentation of L

\section{${ }^{1} \mathrm{H}$ and ${ }^{13} \mathrm{C}-\mathrm{NMR}$ Studies}

The ${ }^{1} \mathrm{H}-\mathrm{NMR}$ spectrum of the free ligand in Fig. S4 showed four singlet signals at $\delta=3.8,3.9,4.89$ and $7.46 \mathrm{ppm}$ corresponding to the protons of $\mathrm{pOCH}_{3}$, $2 \mathrm{mOCH}_{3}, \mathrm{NH}_{2}$, and aromatic group, respectively. The singlet peak at $\delta=10.35 \mathrm{ppm}$ corresponds to the state of $\mathrm{SH}-\mathrm{NH}$ tautomeric. In addition, the ${ }^{13} \mathrm{C}-\mathrm{NMR}$ spectra in Fig. S5 show eight signals, six in the aromatic region of the spectrum corresponding to the carbon atoms of the trimethoxyphenyl and triazole ring, and two signals for the two different types of $-\mathrm{OCH}_{3}$ groups present in the structure. The high-intensity signal at $56.60 \mathrm{ppm}$ was recorded for the $2 \mathrm{C}$ symmetrical $-\mathrm{OCH}_{3}$ group at positions two and six, and the other with low intensity at $60.64 \mathrm{ppm}$ due to the $-\mathrm{OCH}_{3}$ group at position one. While the high-intensity signal at $105.77 \mathrm{ppm}$ due to $2 \mathrm{C}$ is symmetrical at position ortho of the trimethoxyphenyl ring. The signal at $125.86 \mathrm{ppm}$ is due to carbon atom attachment in the triazole ring, and the signal at $139.88 \mathrm{ppm}$ is due to $-\mathrm{COCH}_{3}$ at position one. The signal at $149.63 \mathrm{ppm}$ is due to the $\mathrm{NCN}$ of the triazole ring. The high-intensity signal at $153.28 \mathrm{ppm}$ is due to $2 \mathrm{C}$ symmetrical $-\mathrm{COCH}_{3}$ groups at positions 2 and 6 of the trimethoxyphenyl ring. Moreover, a signal at $167.09 \mathrm{ppm}$ is from the $\boldsymbol{C S}$ of the thione group.

\section{Electronic Spectra and Magnetic Properties}

The UV-Visible absorption spectrum of ligand $\mathrm{L}$ in an ethanol solution is presented in Fig. 1 and summarized in Table 3. It can be observed that two bands at $216 \mathrm{~nm}$ and $259 \mathrm{~nm}$ were allocated to $\pi-\pi^{*}$ transition and a band $305 \mathrm{~nm}$ is assigned to $\mathrm{n}-\pi^{*}$ transition [23].

The electronic spectrum of $\mathrm{C} 1$ complex in DMSO solvent shown in Fig. 2, reveals two spin-allowed bands in the visible region at $656 \mathrm{~nm}$ and $557 \mathrm{~nm}$, which might be related to the transition of ${ }^{4} \mathrm{~T}_{1} \mathrm{~g} \rightarrow{ }^{4} \mathrm{~A}_{2} \mathrm{~g}(\mathrm{~F})(v 2)$ and ${ }^{4} \mathrm{~T}_{1} \mathrm{~g} \rightarrow{ }^{4} \mathrm{~T}_{1} \mathrm{~g}(\mathrm{P})(\mathrm{v} 3)$ respectively. The bands' positions agree with the reported values for an octahedral geometry. Refer to the Tanabe-Sugano diagram, the numerous parameters of ligand field, namely $v_{1}, B^{\prime}, \beta$, and 10Dq have 
Table 3. Conductivity, magnetic and electronic spectra of metal complexes $\mathrm{C} 1-\mathrm{C} 6$

\begin{tabular}{|c|c|c|c|c|c|}
\hline No & 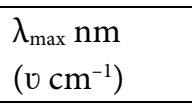 & Assignment & $\mathrm{ohm}^{-1} \mathrm{~cm}^{2} \mathrm{~mol}^{-1}$ & $\begin{array}{l}\mu \mathrm{BM} \\
\text { found (calc) }\end{array}$ & $\begin{array}{l}\text { Suggested } \\
\text { Structure }\end{array}$ \\
\hline \multirow[t]{3}{*}{$\mathrm{L}$} & $305(32786)$ & $\mathrm{n} \rightarrow \pi^{*}$ & - & - & - \\
\hline & $259(38610)$ & $\pi \rightarrow \pi^{*}$ & & & \\
\hline & $216(46296)$ & $\pi \rightarrow \pi^{*}$ & & & \\
\hline \multirow[t]{3}{*}{$\mathrm{C} 1$} & $1243(8042)$ & ${ }^{4} \mathrm{~T}_{1} \mathrm{~g} \rightarrow{ }^{4} \mathrm{~T}_{2} \mathrm{~g}(\mathrm{~F})$ & 13.4 & 4.21 & Octahedral \\
\hline & $656(15243)$ & ${ }^{4} \mathrm{~T}_{1} \mathrm{~g} \rightarrow{ }^{4} \mathrm{~A}_{2} \mathrm{~g}(\mathrm{~F})$ & & (3.87) & \\
\hline & $557(17953)$ & ${ }^{4} \mathrm{~T}_{1} \mathrm{~g} \rightarrow{ }^{4} \mathrm{~T}_{1} \mathrm{~g}(\mathrm{P})$ & & & \\
\hline \multirow[t]{3}{*}{$\mathrm{C} 2$} & $863(11583)$ & ${ }^{3} \mathrm{~A}_{2} \mathrm{~g} \rightarrow{ }^{3} \mathrm{~T}_{2} \mathrm{~g}(\mathrm{~F})$ & 15.6 & 3.11 & Octahedral \\
\hline & $508(19685)$ & ${ }^{3} \mathrm{~A}_{2} \mathrm{~g} \rightarrow{ }^{3} \mathrm{~T}_{1} \mathrm{~g}(\mathrm{~F})$ & & $(2.82)$ & \\
\hline & $414(24154)$ & ${ }^{3} \mathrm{~A}_{2} \mathrm{~g} \rightarrow{ }^{3} \mathrm{~T}_{1} \mathrm{~g}(\mathrm{P})$ & & & \\
\hline \multirow[t]{2}{*}{ C3 } & $507(19723)$ & ${ }^{2} \mathrm{~B}_{1} \mathrm{~g} \rightarrow{ }^{2} \mathrm{~B}_{2} \mathrm{~g}+{ }^{2} \mathrm{Eg}$ & 169.4 & 1.85 & Square planer \\
\hline & $419(23866)$ & ${ }^{2} \mathrm{~B}_{1} \mathrm{~g} \rightarrow{ }^{2} \mathrm{~A}_{1} \mathrm{~g}$ & & (1.73) & \\
\hline \multirow[t]{2}{*}{$\mathrm{C} 4$} & $495(20202)$ & ${ }^{1} \mathrm{~A}_{1} \mathrm{~g} \rightarrow{ }^{1} \mathrm{Eg}$ & 171.3 & Dia & Square planer \\
\hline & $475(20876)$ & ${ }^{1} \mathrm{~A}_{1} \mathrm{~g} \rightarrow{ }^{1} \mathrm{~T}_{1} \mathrm{~g}(\mathrm{G})$ & & & \\
\hline \multirow[t]{3}{*}{$\mathrm{C} 5$} & $325(30796)$ & MLCT & 163.7 & Dia & Tetrahedral \\
\hline & $257(38910)$ & $\mathrm{n} \rightarrow \pi^{*}$ & & & \\
\hline & $251(39840)$ & $\pi \rightarrow \pi^{*}$ & & & \\
\hline \multirow[t]{3}{*}{ C6 } & $550(18181)$ & ${ }^{1} \mathrm{~A}_{1} \mathrm{~g} \rightarrow{ }^{3} \mathrm{~T}_{1} \mathrm{~g}$ & 172.3 & 1.18 & Octahedral \\
\hline & $519(19267)$ & ${ }^{1} \mathrm{~A}_{1} \mathrm{~g} \rightarrow{ }^{3} \mathrm{~T}_{2} \mathrm{~g}$ & & & \\
\hline & $361(27700)$ & LMCT & & & \\
\hline
\end{tabular}

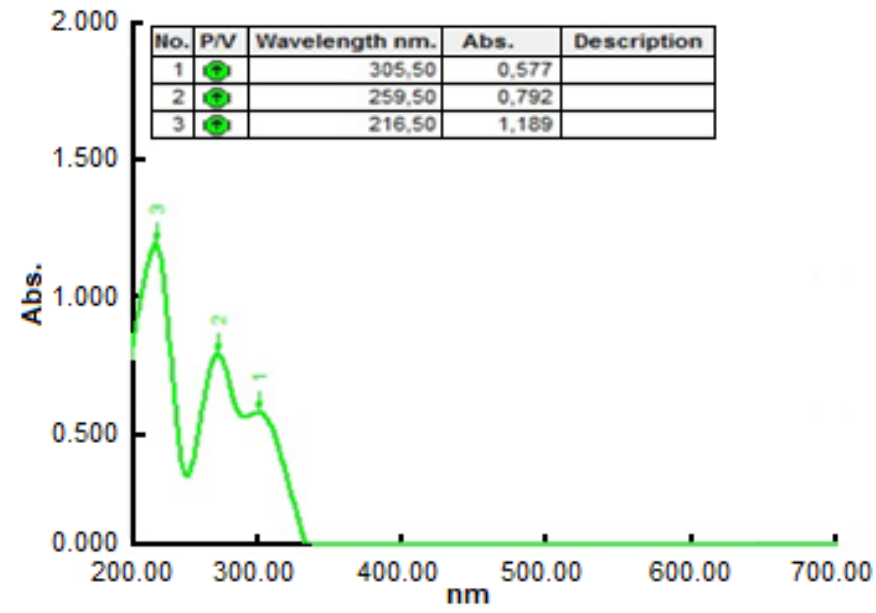

Fig 1. The UV-Vis spectrum of ligand (L)

been calculated for $\left(\mathrm{d}^{7}\right)$ configuration, to be $1243 \mathrm{~nm}$, $608 \mathrm{~cm}^{-1}, 0.66$, and $10052 \mathrm{~cm}^{-1}$, respectively. The factor of the nephelauxetic $(\beta)$ was calculated and found to be 0.66 . Representative bonding was a high degree of ionic from atoms in ligand donor with cobalt(II) ion, hence inter electronic repulsion has been decreased during the process of complexation, as well as the calculated value of $v 1$ to be $8042 \mathrm{~cm}^{-1}$ due to the transition ${ }^{4} \mathrm{~T}_{1} \mathrm{~g} \rightarrow{ }^{4} \mathrm{~T}_{2} \mathrm{~g}(\mathrm{~F})$. The

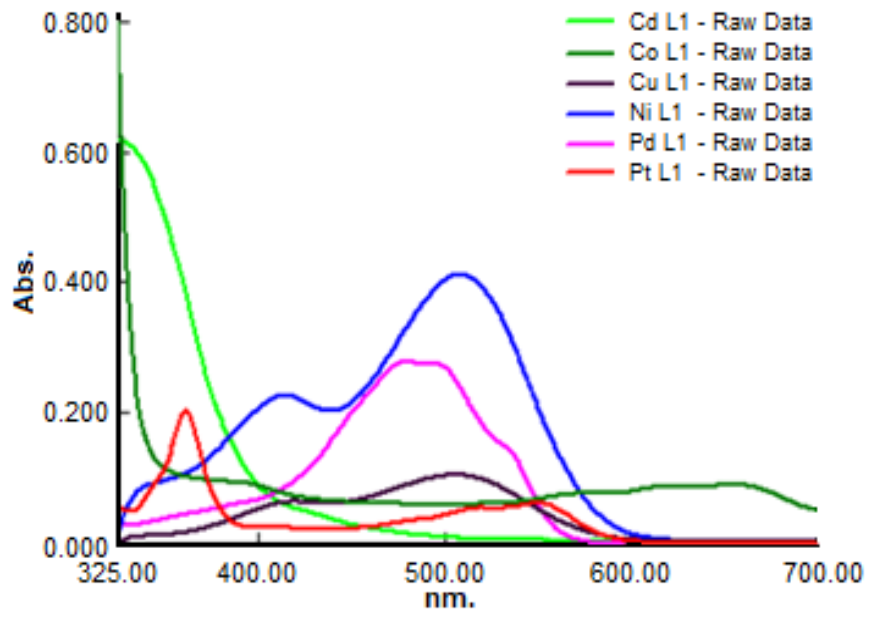

Fig 2. The UV-Vis spectrum of metal complexes

transition ratio $v 2 / v 1$ gave a value of 1.89 provided further indications for octahedral geometry for the Co(II) complex. The magnetic susceptibility of $4.21 \mathrm{BM}$ indicates that the cobalt(II) complex is paramagnetic. The molar conductivity of 13.42 means that the complex is nonconductive, as shown in Table 3. In addition to this data, the results of elemental (CHNS) analysis, flame atomic absorption, and FT-IR spectrum united in 
opinion with this condition and can be suggested octahedral structure for the CoL1 complex, as expressed in Fig. 4(a) [24].

The electronic spectrum of the C2 complex in DMSO solution shows two spin-allowed bands $508 \mathrm{~nm}$ and $414 \mathrm{~nm}$ allocated to ${ }^{3} \mathrm{~A}_{2} \mathrm{~g} \rightarrow{ }^{3} \mathrm{~T}_{1} \mathrm{~g}$ (F) (v2) and ${ }^{3} \mathrm{~A}_{2} \mathrm{~g} \rightarrow{ }^{3} \mathrm{~T}_{1} \mathrm{~g}(\mathrm{P})(\mathrm{v})$ transitions, respectively. These bands indicate an octahedral geometry around $\mathrm{Ni}$ (II) ion. At the same time, the value of the third transition $(v 1)$ was calculated by fitting the ratio $v 3 / v 2$ for the octahedral $\mathrm{d}^{8}$ system of Tanabe-Sugano diagram. The calculated value of $\nu 1$ was $863 \mathrm{~nm}$ due to the transition ${ }^{3} \mathrm{~A}_{2} \mathrm{~g} \rightarrow{ }^{3} \mathrm{~T}_{2} \mathrm{~g}(\mathrm{~F})$. As well as the ligand field parameters ( $\mathrm{B}^{\prime}, \beta$, and $\left.10 \mathrm{Dq}\right)$ have been calculated using the Tanabe-Sugano diagram for the $\mathrm{d}^{8}$ system and found to be $726 \mathrm{~cm}^{-1}, 0.673$, and $15254 \mathrm{~cm}^{-1}$, respectively. The constant field splitting (10Dq) value will be $11583 \mathrm{~cm}^{-1}$, approximately close to the first transition $(v 1)$. The $(v 2 / v 1)$ ratio is 1.96 , indicating octahedral geometry less than tetrahedral stereochemistry of $\mathrm{Ni}(\mathrm{II})$. The magnetic value for $\mathrm{Ni}(\mathrm{II})$ in Table 3 gave a magnetic moment value of $3.11 \mathrm{BM}$, and it is about the range of 2.83.5 BM with octahedral geometry for $\mathrm{Ni}(\mathrm{II})$ ion. The conductivity refers to the non-ionic performance of this complex. Thus from the data above and those obtained from FT-IR spectra and flame atomic absorption, an octahedral geometry around $\mathrm{Ni}(\mathrm{II})$ ion can be suggested as given in Fig. 4(a) [25-26].

The $\mathrm{d}^{9}$ ion is characterized by a large distortion from the octahedral symmetry, and the band is asymmetrical. Several transformations have occurred, and these transitions have emerged, which cannot be easily set without ambiguity. The free ion ${ }^{2} \mathrm{D}$ term is expected to split in a crystal field in the same way as the ${ }^{5} \mathrm{D}$ term of the $\mathrm{d}^{4}$ ion, and a similar interpretation of the spectra is likewise expected. The spectrum of copper(II) complex in DMSO solution shows one broadband at $507 \mathrm{~nm}$ which agrees to ${ }^{2} \mathrm{~B}_{1} \mathrm{~g} \rightarrow{ }^{2} \mathrm{~B}_{2} \mathrm{~g}+{ }^{2} \mathrm{Eg}\left(v_{2}+v 3\right)$ transition, and shoulder band at $419 \mathrm{~nm}$ allocated to ${ }^{2} \mathrm{~B}_{1} \mathrm{~g} \rightarrow{ }^{2} \mathrm{~A}_{1} \mathrm{~g}(v 1)$ transitions. The position of these bands is to approve with configuration highly distorted octahedral geometry. The magnetic moment value was $1.85 \mathrm{BM}$ at room temperature, approved with square planar geometry for the $\mathrm{Cu}(\mathrm{II})$ complex. The conductivity in DMF showed that the complex has electrolytic nature. From the electronic spectra data, FT-IR spectroscopy data and flame atomic absorption can be suggested as a square planar geometry around the $\mathrm{Cu}(\mathrm{II})$ ion, as can be seen in Fig.(4(b) [27].

The $\mathrm{Pd}(\mathrm{II})$ ion has a $\left(\mathrm{d}^{8}\right)$ configuration that favors square planar geometry formation. The electronic spectrum of $\mathrm{C} 4$ complex in (DMSO) displays two spinallowed at $495 \mathrm{~nm}$ and $475 \mathrm{~nm}$ and are assigned to $1 \mathrm{~A}_{\mathrm{gg}}$ $\rightarrow 1 \mathrm{~B}_{1 \mathrm{~g}}$ and $1 \mathrm{~A}_{1} \mathrm{~g} \rightarrow 1 \mathrm{Eg}$ transitions in a square planar geometry, respectively. The magnetic moment of the solid complex showed diamagnetic behavior (Table 3) approved with square-planar geometry of $\mathrm{Pd}(\mathrm{II})$ ion. The conductivity measurement in DMF showed that the complex has a higher conducting property (Table (3)), and therefore the two $\mathrm{Cl}^{-}$ions are located outside the coordination. From these results and that of the elemental analysis, FT-IR, and flame atomic absorption studies, it can be suggested as square planar geometry around the $\mathrm{Pd}(\mathrm{II})$ ion as shown in Fig. 4(b) [28].

The electronic spectrum of the C6 complex showed bands at $550 \mathrm{~nm}, 519 \mathrm{~nm}$, and $361 \mathrm{~nm}$ assigned to ${ }^{1} \mathrm{~A}_{1} \mathrm{~g}$ $\rightarrow{ }^{3} \mathrm{~T}_{1} \mathrm{~g},{ }^{1} \mathrm{~A}_{1} \mathrm{~g} \rightarrow{ }^{3} \mathrm{~T}_{2} \mathrm{~g}$, and (LMCT), respectively. The complex may have octahedral coordination of the central metal ion by the surrounding ligands. The magnetic moment value of solid complex (1.18 BM) for Pt(IV) is observed. It agrees with the octahedral geometry. The increase in the magnetic moment is expected due to the presence of the contribution of spin-orbital coupling. The conductance measurements indicate the ionic behavior of this complex according to these results and that of the elemental analysis, FT-IR, and flame atomic absorption studies. Therefore, $\mathrm{Pt}(\mathrm{IV})$ ion has an octahedral geometry, as shown in Fig. 4(a) [29].

The electronic spectrum of the C5 complex has no (d-d) transition and belongs to $\mathrm{d}^{10}$. The prepared complexes are off-white in color, with the diamagnetic being expected. Therefore, the UV-Vis spectrum of this complex shows a relative change in the bands' position compared to that of the free ligand (L). The UV-Vis spectrum of C5 in DMSO displayed three bands at 325, 257 , and $251 \mathrm{~nm}$, respectively, assigned to (MLCT), ( $\mathrm{n} \rightarrow$ $\left.\pi^{\star}\right)$ and $\left(\pi \rightarrow \pi^{*}\right)$ transition, respectively. The 
conductivity measurements indicate the ionic conducting addition to the results of elemental analysis, we can suggest a tetrahedral geometry around $\mathrm{Cd}(\mathrm{II})$ ion as illustrated in Fig. 4(c) [30].

\section{Thermal Analyses (TGA-DSC)}

The thermogravimetric curve of ligand $\mathrm{L}$ is shown in Fig. 3(a) at the temperature range of $10-696^{\circ} \mathrm{C}$ to reveal two decomposition steps. The TGA peak observed at temperature range of $100-355{ }^{\circ} \mathrm{C}$ indicated the loss of $2 \mathrm{OCH}_{3}, \mathrm{NH}_{2}$ fragment (det. $=2.846 \mathrm{mg}, 27.77 \%$, calc. $=$ $27.65 \%)$. The second step recorded at temperature range of $355-696{ }^{\circ} \mathrm{C}($ det. $=3.246 \mathrm{mg}, 31.68 \%$, calc. $=32.62 \%)$ indicated the loss of $\mathrm{C}_{7} \mathrm{H}_{8}$. The final residue of the complex recorded above $696^{\circ} \mathrm{C}$ attributed to $\mathrm{C}_{2} \mathrm{~S}, \mathrm{~N}_{3} \mathrm{O}$, (det. $=4.001 \mathrm{mg}, 39.04 \%$, calc. $=40.42 \%)$. The DSC curve indicates exothermic decomposition processes at $246.5^{\circ} \mathrm{C}$ $(56.3 \mathrm{~mW})$ and $500.4^{\circ} \mathrm{C}(86.2 \mathrm{~mW})$. The TGA curves of complex PdL1 displayed thermal decomposition with loss weight percent (det. $=1.165 \mathrm{mg}, 11.3 \%$, calc. $=11.9 \%)$ in the temperature range $25-100{ }^{\circ} \mathrm{C}$ indicating the cleavage of chloride ions present in the outside of the coordination sphere and one molecule of water in Pd(II) complex. As well as the degradation of the organic molecule started before the temperature of $200^{\circ} \mathrm{C}$. The second step of TGA curve exhibited (det. $=2.407 \mathrm{mg}, 23.0 \%$, calc. $=22.64 \%$ ) due to decomposition of $\mathrm{C}_{6} \mathrm{H}_{3} \cdot 3 \mathrm{OCH}_{3}$ at $100-345^{\circ} \mathrm{C}$, and the third step is assigned to the loss of $\mathrm{PdO}, \mathrm{C}_{13} \mathrm{H}_{16} \mathrm{~N}_{8} \mathrm{O}_{2} \mathrm{~S}$ at $345-699^{\circ} \mathrm{C}($ det. $=6.46 \mathrm{mg}, 61.77 \%$, calc. $=61.19 \%)$ (Fig. $3(\mathrm{~b})$ ). The final residue of the complex recorded above behavior of the complex. According to these results, in

$699^{\circ} \mathrm{C}$ attributed to CS (det. $=0.428 \mathrm{mg}, 4.08 \%$, calc. $=$ $5.01 \%)$. The DSC curve indicated exothermic decomposition processes at $115.7{ }^{\circ} \mathrm{C}(43.2 \mathrm{~mW})$ and $490.3^{\circ} \mathrm{C}(95.9)$

\section{Biological Activity}

The antibacterial potency of ligand L1 and their $\mathrm{Ni}(\mathrm{II}), \mathrm{Cu}(\mathrm{II}), \mathrm{Co}(\mathrm{II}), \mathrm{Pd}(\mathrm{II}), \mathrm{Cd}(\mathrm{II})$, and $\mathrm{Pt}(\mathrm{IV})$ metal complexes was evaluated in vitro against bacteria Staphylococcus aureus (G-positive) and Escherichia coli (G-negative). At a $50 \mu \mathrm{g} / \mathrm{mL}$ concentration, a freshly prepared liquid agar medium $(20 \mathrm{~mL} /$ Petri dish) was poured into each Petri dish, and the plates were dried by placing in an incubator at $37{ }^{\circ} \mathrm{C}$ for $1 \mathrm{~h}$. Then standardized culture of microorganisms was spread on each Petri dish by an L-shaped spreader. Wells $(6 \mathrm{~mm})$ were made using an agar punch and, each well was labeled accordingly. A control solvent DMSO was also included in the test. The test compound and standard drug solutions (Erythromycin, $50 \mu \mathrm{g} / \mathrm{mL}$ ) were made in DMSO and added to each well separately, and the Petri dish was kept aseptically for 1-h diffusion of the sample. After the diffusion was complete, all the Petri dishes were kept for incubation at $37{ }^{\circ} \mathrm{C}$ for $24 \mathrm{~h}$. Then the diameter of the zone of inhibition was measured in ( $\mathrm{mm}$ ). The tested ligand (L) and metal ion complexes have shown less activity than a standard Erythromycin. Metal ion complexes have been exhibited much better activity than the free ligand, $\mathrm{L}$. The inhibition zone data for the entire complexes at $50 \mu \mathrm{g} / \mathrm{mL}$ as compared to free ligand (L1) should be discussed among the platinum(IV) complex,
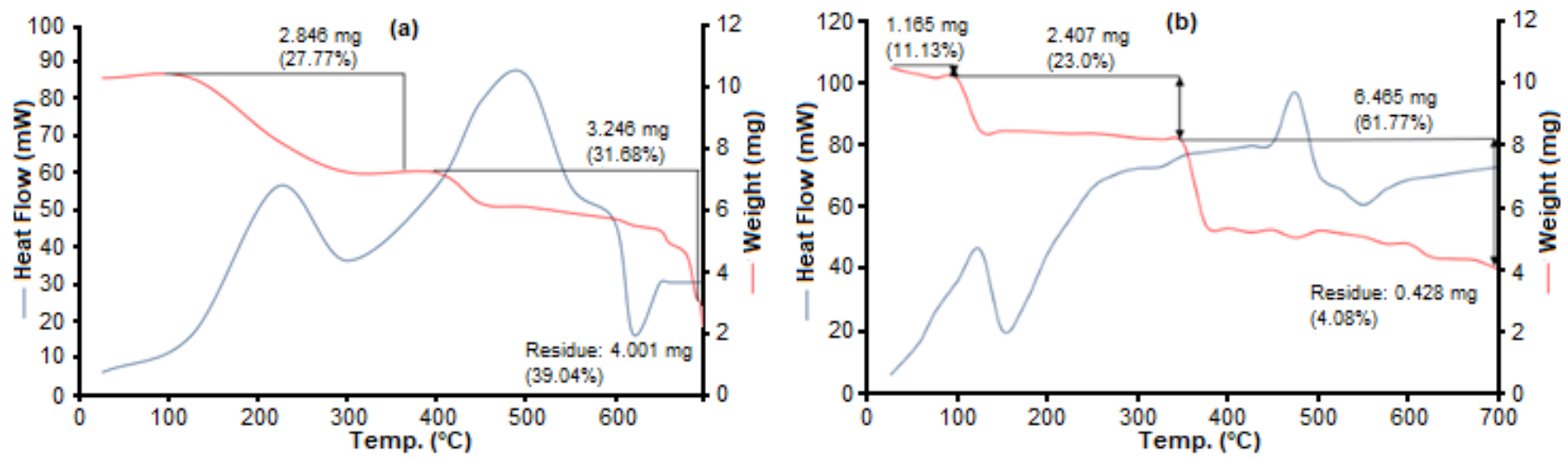

Fig 3. TG-DSC thermogram of (a) L and (b) PdL 


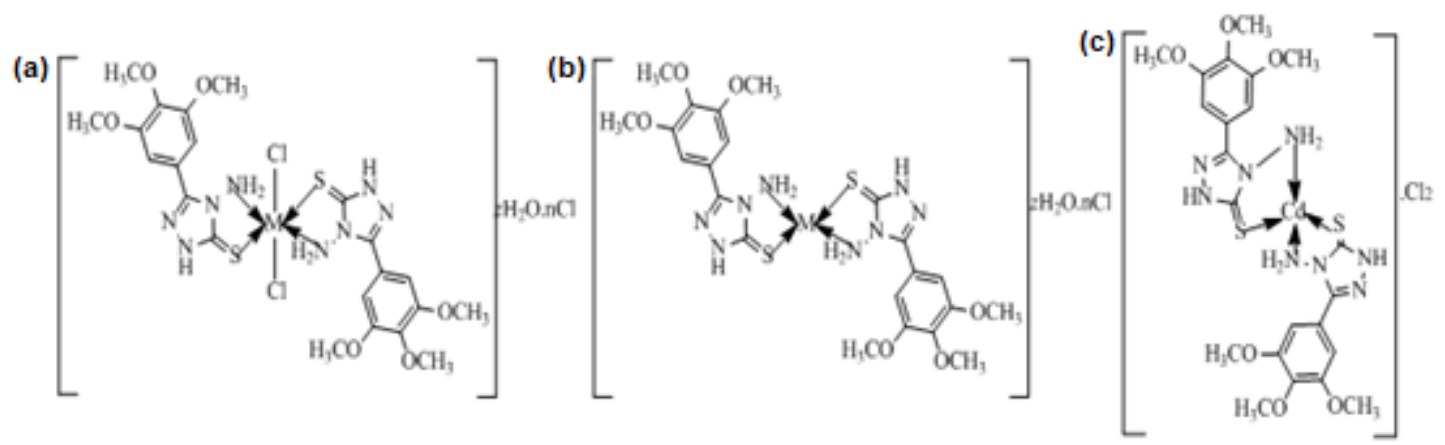

Fig 4. (a) Octahedral for $\mathrm{Co}^{2+}, \mathrm{Ni}^{2+}$ and $\mathrm{Pt}^{+4}$ complexes, (b) square planar for $\mathrm{Cu}^{2+}$ and $\mathrm{Pd}^{+2}$ complex, and (c) tetrahedral for $\mathrm{Cd}^{2+}$ complex

Table 4. The inhibition zones ( $\mathrm{mm}$ ) of (L) and their metal complexes against $S$. aureus and E. coli

\begin{tabular}{llcc}
\hline $\mathrm{No}$ & Compound & $(\mathrm{G}+)$ S. aureus & $(\mathrm{G}-)$ E. coli \\
\hline 1 & $\mathrm{C}_{11} \mathrm{H}_{14} \mathrm{~N}_{4} \mathrm{O}_{3} \mathrm{~S}$ & 7 & 8 \\
2 & {$\left[\mathrm{Co}(\mathrm{L})_{2} \mathrm{Cl}_{2}\right]$} & 19 & 16 \\
3 & {$\left[\mathrm{Ni}(\mathrm{L})_{2} \mathrm{Cl}_{2}\right]$} & 9 & 13 \\
4 & {$\left[\mathrm{Cu}(\mathrm{L})_{2}\right] \mathrm{Cl}_{2}$} & 9 & 10 \\
5 & {$\left[\mathrm{Pd}(\mathrm{L})_{2}\right] \mathrm{Cl}_{2} \cdot \mathrm{H}_{2} \mathrm{O}$} & 23 & 25 \\
6 & {$\left[\mathrm{Cd}(\mathrm{L})_{2}\right] \mathrm{Cl}_{2}$} & 21 & 24 \\
7 & {$\left[\mathrm{Pt}(\mathrm{L})_{2} \mathrm{Cl}_{2}\right] \mathrm{Cl}_{2} \cdot 2 \mathrm{H}_{2} \mathrm{O}$} & 28 & 29 \\
8 & DMSO & 0 & 0 \\
9 & Erythromycin & 35 & 35 \\
\hline
\end{tabular}

which has the highest inhibitory effect against the bacteria. The antibacterial activity of the free ligand and its complexes showed the order: PtL1 > PdL1 > CdL1 > CoL1 $>$ NiL1 $>$ CuL1 $>$ L1 and PtL1 was found to have the best effect [31]. In general, the metal complexes show antibacterial activity, and the following five principal factors should be considered. The ligands' chelate effect that is bound to metal ions in a bidentate fashion through NS and NO moiety of the ligands show higher antimicrobial efficiency than the complexes uni dentate, respectively, like pyridine. However, the total charge of the complexes in general, the antimicrobial activity decreases with the order of cationic $>$ neutral $>$ anionic complex. Table 4 represents the inhibition zones $(\mathrm{mm})$ for the $\mathrm{L} 1$ and its complexes against the bacteria in DMSO solvent as control. The free ligand exhibited low activity against all bacteria at around $7-8 \mathrm{~mm}$, and the PtL1, PdL1, and CdL1 showed the greatest activity against Staphylococcus aureus and Escherichia coli at 28-29, 2325 , and 21-24 $\mathrm{mm}$, respectively.

\section{- CONCLUSION}

In this research work, new transition metal complexes of cobalt(II), nickel(II), copper(II), palladium(II), cadmium(II) and platinum(IV) with bidentate ligand of 4-amino-5-(3,4,5-trimethoxyphenyl) -4I-1,2,4-triazole-3-thiol were synthesized and characterized. The results obtained from spectra and elemental analyses indicated the tetrahedral geometry around $\mathrm{Cd}(\mathrm{II})$ ion, square-planner for $\mathrm{Cu}$ and $\mathrm{Pd}(\mathrm{II})$, and octahedral geometry around $\mathrm{Co}(\mathrm{II}), \mathrm{Ni}(\mathrm{II})$, and $\mathrm{Pt}(\mathrm{IV})$. The Inhibition zones of ligand (L) and their metal complexes with concentrations $(50 \mu \mathrm{g} / \mathrm{mL})$ against Staphylococcus aureus and Escherichia coli showed the order of $\mathrm{PtL}>\mathrm{PdL}>\mathrm{CdL}>\mathrm{CoL}>\mathrm{NiL}>\mathrm{CuL}$ $>$ L. Thus, further study on this approach could pave the way for developing 1,2,4-triazole-metal complex-based antibacterial agents.

\section{- ACKNOWLEDGMENTS}

The authors are so thankful to the pharmacy faculty members, Babylon University for facilitating the measurements of IR and UV spectra. We are so grateful to Mustansiriyah University, College of Science, Chemistry Department for supporting the work by providing chemicals and measuring the complexes' molar conductance and magnetic susceptibility.

\section{- REFERENCES}

[1] Sugiyarto, K.H., Louise, I.S.Y., and Wilujeng, S.S., 2020, Preparation and powder XRD analysis of tris(2,2'-bipyridine)nickel(II) trifluoroacetate, Indones. J. Chem., 20 (4), 833-841. 
[2] Timur, İ., Kocyigit, Ü.M., Dastan, T., Sandal, S., Ceribası, A.O., Taslimi P., Gulcin, İ., Koparir, M., Karatepe, M., and Çiftçi, M., 2019, In vitro cytotoxic and in vivo antitumoral activities of some aminomethyl derivatives of 2,4-dihydro-3H-1,2,4triazole-3-thiones-Evaluation of their acetylcholines terase and carbonic anhydrase enzymes inhibition profiles, J. Biochem. Mol. Toxicol., 33 (1), e22239.

[3] Kaproń, B., Łuszczki, J.J., Płazińska, A., Siwek, A., Karcz, T., Gryboś, A., Nowak, G., Makuch-Kocka, A., Walczak, K., Langner, E., Szalast, K., Marciniak, S., Paczkowska, M., Cielecka-Piontek, J., Ciesla, L.M., and Plech, T., 2019, Development of the 1,2,4triazole-based anticonvulsant drug candidates acting on the voltage-gated sodium channels. Insights from in-vivo, in-vitro, and in-silico studies, Eur. J. Pharm. Sci., 129, 42-57.

[4] Sugiyarto, K.H., Yunita, I., and Goodwin, H.A., 2020, Preparation, electronic properties, and powder-XRD structure analysis of 3,5-Bis(pyridin-2-yl)-H-1,2,4triazoledichloridocopper(II), Indones. J. Chem., 20 (6), 1422-1429.

[5] Obaid, S.M.H., Sultan, J.S., and Al-Hamdani, A.A.S., 2020, Synthesis, characterization and biological efficacies from some new dinuclear metal complexes for base 3-(3,4-dihydroxy-phenyl)-2-[(2-hydroxy-3methylperoxybenzylidene)-amino]-2-methyl propio nic acid, Indones. J. Chem., 20 (6), 1311-1322.

[6] Rasyda, Y.A., Widowati, M.K., Marliyana, S.D., and Rahardjo, S.B., 2021, Synthesis, characterization and antibacterial properties of nickel(II) complex with 4aminoantipyrine ligand, Indones. J. Chem., 21 (2), 391-399.

[7] Idrees, M., Nasare, R.D., and Siddiqui, N.J., 2016, Synthesis of S-phenacylated trisubstituted 1,2,4triazole incorporated with 5-(benzofuran-2-yl)-1phenyl-1H-pyrazol-3-yl moiety and their antibacterial screening, Chem. Sin., 7 (4), 28-35.

[8] Özadalı, K., Özkanlı, F., Jain, S., Rao, P.P.N., and Velázquez-Martínez, C.A., 2012, Synthesis and biological evaluation of isoxazolo[4,5-d]pyridazin-4$(5 \mathrm{H})$-one analogues as potent anti-inflammatory agents, Bioorg. Med. Chem., 20 (9), 2912-2922.

[9] Kanagarajan, V., Thanusu, J., and Gopalakrishnan, M., 2011, Synthesis and in vitro microbiological evaluation of novel 2,4-diaryl-3-azabicyclo[3.3.1] nonan-9,5'-spiro-1',2',4'-triazolidine-3'-thiones, Med. Chem. Res., 21 (12), 3965-3972.

[10] Dallavalle, F., Gaccioli, F., Franchi-Gazzola, R., Lanfranchi, M., Marchiò, L., Pellinghelli, M.A., and Tegoni, M., 2002, Synthesis, molecular structure, solution equilibrium, and antiproliferative activity of thioxotriazoline and thioxotriazole complexes of copper(II) and palladium(II), J. Inorg. Biochem., 92 (2), 95-104.

[11] Al-Masoudi, N.A., Abdullah, B.H., Essa, A.H., Loddo, R., and LaColla, P., 2010, Platinum and palladium-triazole complexes as highly potential antitumor agents, Arch. Pharm., 343 (4), 222-227.

[12] Kapri, K.P., Singar, S.B., Khanal, S., and Shakya, B., 2020, Synthesis of Schiff bases of 4-amino-5-(2hydroxyphenyl)-4H-1,2,4-triazole-3-thiol as potent antimicrobial agents, Amrit Res. J., 1 (1), 29-36.

[13] Devkota, K., Pathak, G., and Shakya, B., 2020, Synthesis and evaluation of Schiff bases of 4-amino5-(chlorine substituted phenyl)-4H-1,2,4-triazole3-thione as antimicrobial agents, J. Nepal Chem. Soc., 41 (1), 26-35.

[14] Namratha, B., and Gaonkar, S.L., 2014, 1,2,4Triazoles: Synthetic strategies and pharmacological profiles, Int. J. Pharm. Pharm. Sci., 6 (8), 73-80.

[15] Bharty, M.K., Bharti, A., Chaurasia, R., Chaudhari, U.K., Kushawaha, S.K., Sonkar, P.K., and Butcher, R.J., 2019, Synthesis and characterization of Mn(II) complexes of 4-phenyl(phenyl-acetyl)-3thiosemicarbazide, 4-amino-5-phenyl-1,2,4triazole-3-thiolate, and their application towards electrochemical oxygen reduction reaction, Polyhedron, 173, 114125.

[16] Murti, Y., Agnihotri, R., and Pathak, D., 2011, Synthesis, characterization and pharmacological screening of some substituted 1,2,3- \& 1,2,4triazoles, Am. J. Chem., 1 (2), 42-46.

[17] Majeed A.S., 2010, Synthesis, structure and 
antibacterial activity of some 2-amino-5-(2acetyloxyphenyl)-1,3,4-thiadiazole complexes, $A l$ Mustansiriya J. Sci., 21 (5), 195-204.

[18] Yousif, E., Hameed, A., and Ameer, A., 2005, Synthesis and characterization of complexes of some transition metals with 2-amino-5-(4-hexyloxyphenyl) -1,3,4-thiadiazole, J. Al-Nahrain Univ., 8 (1), 9-11.

[19] Narayana, B, and Gajendragad, M., 1997, Complexes of $\mathrm{Zn}(\mathrm{II}), \mathrm{Pd}(\mathrm{II}), \mathrm{Hg}(\mathrm{II}), \mathrm{Pb}(\mathrm{II}), \mathrm{Cu}(\mathrm{I}), \mathrm{Ag}(\mathrm{I})$, and $\mathrm{Ti}(\mathrm{I})$ with 4-amino-5-merccapto-3-(o-tolyloxymethyl)1,2,4-troazol, Turk. J. Chem., 21 (1), 71-76.

[20] Sliverstein, R., Webster, F.X., and Kiemle, D.J., 2005, Spectrometric Identification of Organic Compounds, $7^{\text {th }}$ Ed., John Wiley \& Sons, Hoboken, New York.

[21] Flifel, I., and Kadhim, S., 2012, Synthesis and characterization of 1,3,4-oxadiazole derivatives with some new transition metal complexes, J. Kerbala Univ., 10 (3), 197-209.

[22] Abd El-Razek, S.E., El-Gamasy, S.M., Hassan, M., Abdel-Aziz, M.S., and Nasr, S.M., 2020, Transition metal complexes of a multidentate Schiff base ligand containing guanidine moiety: Synthesis, characterization, anticancer effect, and antimicrobial activity, J. Mol. Struct., 1203, 127381.

[23] Anacona, J.R., Ruiz, K., Loroño, M., and Celis, F., 2019, Antibacterial activity of transition metal complexes containing a tridentate NNO phenoxymethylpenicillin-based Schiff base. An antiMRSA iron(II) complex, Appl. Organomet. Chem., 33 (4), e4744.

[24] Rapheal, P.F., Manoj, E., Kurup, M.R.P., and Fun, HK, 2021, Nickel(II) complexes of N(4)-substituted thiosemicarbazones derived from pyridine-2carbaldehyde: Crystal structures, spectral aspects and Hirshfeld surface analysis, J. Mol. Struct., 1237, 130362.

[25] Hamil, A., Khalifa, K.M., Almutaleb, A.A., and Nouradean, M.Q., 2020, Synthesis, characterization and antibacterial activity studies of some transition metal chelates of $\mathrm{Mn}$ (II), $\mathrm{Ni}(\mathrm{II})$ and $\mathrm{Cu}(\mathrm{II})$ with Schiff base derived from diacetylmonoxime with $\mathrm{O}$ phenylenediamine, Adv. J. Chem. A, 3 (4), 524-533.

[26] Kargar, H., Torabi, V., Akbari, A., BehjatmaneshArdakani, R., Sahraei, A., and Tahir, M.N., 2020, $\mathrm{Pd}(\mathrm{II})$ and $\mathrm{Ni}(\mathrm{II})$ complexes containing an asymmetric Schiff base ligand: Synthesis, X-ray crystal structure, spectroscopic investigations and computational studies, J. Mol. Struct., 1205, 127642.

[27] Adachi, J., Mori, T., Inoue, R., Naito, M., Le, N.H.T., Kawamorita, S., and Ariga, K., 2020, Emission control by molecular manipulation of doublepaddled binuclear $\mathrm{P}^{\mathrm{II}}$ complexes at the air-water interface, Chem. Asian J., 15 (3), 406-414.

[28] Yang, Y.J., Li, Y.H., Liu, D., and Cui, G.H., 2020, A dual-responsive luminescent sensor based on a water-stable $\mathrm{Cd}(\mathrm{II})$-MOF for the highly selective and sensitive detection of acetylacetone and $\mathrm{Cr}_{2} \mathrm{O}_{7}{ }^{2-}$ in aqueous solutions, CrystEngComm, 22 (7), 11661175.

[29] Tenorio, K.V., Fortunato, A.B., Moreira, J.M., Roman, D., D'Oliveira, K.A., Cuin, A., Brasil, D.M., Pinto, L.M.C., Colman, T.A.D., and Carvalho, C.T., 2020, Thermal analysis combined with X-ray diffraction/Rietveld method, FT-IR and UV-vis spectroscopy: Structural characterization of the lanthanum and cerium(III) polycrystalline complexes, Thermochim. Acta, 178662.

[30] Djunaidi, M.C., Setiyo, P.D., Lusiana, R.A., and Anggun Y., 2020, In-situ ionic imprinted membrane (IIM) synthesis based on acetic polyeugenoxy acetyl tiophen methanolate for gold(III) metal ion transports, Indones. J. Chem., 20 (6), 1323-1331.

[31] Bisceglie, F., Bacci, C., Vismarra, A., Barilli, E., Pioli, M., Orsoni, N., and Pelosi, G., 2020, Antibacterial activity of metal complexes based on cinnamaldehyde thiosemicarbazone analogues, $J$. Inorg. Biochem., 203, 110888. 